education has increased the levels of formation of acmeological competence.

The research does not cover all aspects of the problem. The study of modern ways of self-education and the conditions of cadets` selfeducation activities could become the priorities for further research.

\title{
References:
}

1. Large Explanatory Dictionary of Modern Ukrainian Language / [ed. Busel, V.T.] (2005). Kyiv; Irpyn: VTF «Perun». (in Ukrainian)

2. Goncharenko, S. (1997). Ukrainian Pedagogical Dictionary. Kyiv: Lybid. (in Ukrainian)

3. Mayboroda, A. O. (2014). Acmeological Competence Formation of future Specialist of Rescue Service in the Process of Professional Training: thesis. ... cand. ped. sciences: spec. 13.00.04 - theory and methodology of professional education. Pereyaslav-Khmelnyzhkiy. (in Ukrainian)

4. Chebotareva, O. S. (2008). Self-educated competence of future specialists as the criteria of training quality [mode]. Scolars' notes: e-journal. - Course: published KGU, 5. Retrieved from: http://www. scientificnotes.ru (in Russian)

\section{PECULIARITIES OF TEXT SELECTION FOR HIGH SCHOOL STUDENTS}

\section{Serhii Nikonenko ${ }^{1}$}

DOI: https://doi.org/10.30525/978-9934-588-84-6-5

Working on texts is an essential part of learning a foreign language. Unfortunately, modern teaching of the foreign language, especially in Ukraine, provides insufficient attention to texts as objects that have a direct connection between the country and its language.

The purpose of the study is to summarize the requirements that the texts for reading must meet during foreign language lessons and transforming them into a template.

Firstly, let's focus on the official programs of MON of Ukraine. «Curricula in foreign languages for secondary schools and specialized schools with in-depth study of foreign languages, grades 10-11» indicates that at the end of the study period students of 11 grade should have the following results in texts reading [1, p. 37]:

${ }^{1}$ Kryvyi Rih State Pedagogical University, Ukraine 
- to read: simple texts with facts, concerning the students' interests;

- to understand: description of events, feelings, wishes in personal letters; simple posts on the Internet; content of standard official correspondence; simple information of advertisements in newspapers and magazines that are not overloaded with abbreviations; most of the factual information on familiar topics; content of concise descriptions on information boards; clear and simple instructions for various technical devices; brief safety instructions; detailed descriptions of the place, events, feelings; plot of stories, simple stories, etc.;

- to select: information on the packaging about cooking and use of medicine;

- to determine: relevance of the article or report to a given topic;

- to highlight: the content of simple articles on familiar topics.

Secondly, it is noted that high school students should be able to: read quickly; choose material for reading, depending on their interests and desires; recollect the meaning of unknown words by word-forming elements, context, similarity to the words of the native language; predict the content of the text; trace the development of the plot; read texts of various genres; apply general competencies to understand the content of the text; use a dictionary; choose from the texts the main [2].

Thirdly, according to the "Whole language» philosophy of learning a foreign language, the organization of reading must meet the following conditions [3]:

1. In the course of working on a text, all language processes must be integrated.

2. Students should read interesting, authentic texts, aesthetically designed, appropriate to their age.

3. Texts should present literary works (story, fairy tale, poem, novel, etc.).

4. Students should have the opportunity to discuss, share their impressions.

5. Tasks that precede or follow the reading shouldn't seem artificial. They should provide real opportunities for communication, expressing thoughts, interests, and feelings of readers, building their judgments.

Thus, we can draw an intermediate conclusion that the texts used for reading while learning a foreign language should: correspond to the topic being studied at the moment; be diverse (fiction texts, journalistic, technical, related to household information, which contains features, specific to Internet communication, etc.); relate to the interests of the student; be authentic and aesthetically designed; contain a clear 
storyline or main idea; have the possibility to make natural, not artificial, exercises out of them.

Further, it is known that the traditional method of working with foreign texts involves three main stages of work: pre-textual, textual (or textbased), and post-textual. All the given stages of reading go through the entire period of schooling, gaining in-depth exercises, and becoming more difficult each year with the help of texts provided by the textbook or chosen by students for reading. It is important to note that during any test (especially exams) the pre-reading stage of working with text is absent, or not as much obvious as during the foreign language classes. Students don't have tips that could facilitate their work in the later stages of text processing; there is no external directive to perception and understanding, except for their motivation. Such a preliminary directive will also be absent in their later real life. Therefore, while working with texts in senior classes, the use of the pre-textual stage by the teacher should be minimized, i.e. students should learn to prepare themselves for reading and working with the text independently, develop their strategies for overcoming difficulties that may arise during the work. It is possible to achieve by using not only texts from the textbook, but by selecting additional texts on the subject being studied. At the same time, another question arises - to what extent does the text, which is being chosen for students, corresponds to their skills and needs?

To answer this question, first of all, it is worth mentioning the article by T. M. Pshonik, who mentions the term «operability» as one of the criteria for selecting materials for reading, along with «content relevance» and «readability». Under the operational text, the author means the text which can be used for the development of students' competence in reading, i.e. the texts with the help of which teachers «correlate students' basic knowledge with the content of the text, optimize previously acquired knowledge, set goals, ask leading questions, introduce new vocabulary, etc.» [4 - our translation]. Hence, the next intermediate conclusion may determine that the text selected for the work must meet the following criterion: the possibility of operation to achieve the goal set in the lesson.

Secondly, some factors affect the complexity of working with the text, which the teacher must check when selecting materials for processing (based upon advice for 4-8 grades) [5]: age appropriateness; complexity of ideas; structure and coherence of the text; syntactic structure of the text; vocabulary difficulty; length of the text. 
Table 1

A template for analyzing the text's relevance to high school students' learning requirements, needs and skills

\begin{tabular}{|l|l|}
\hline $\begin{array}{l}\text { Author of the text: } \\
\text { Text title: } \\
\text { Source of the text: }\end{array}$ \\
\hline Category & Notes \\
\hline Text genre: fiction; journalistic etc. & \\
\hline Educational topic & \\
\hline Students' needs & \\
\hline Students' interests & \\
\hline Students' age & \\
\hline Previous students' experience on the given topic & \\
\hline Elements that may make the understanding of text difficult & \\
\hline Elements that may ease the understanding of the text & \\
\hline Text structure & \\
\hline Visual design of the text: according to requirements; aesthetic, etc. & \\
\hline Presence of unfamiliar words and their number & \\
\hline Presence of specific vocabulary & \\
\hline Features of sentences & \\
\hline Features of tenses & \\
\hline General operability of the text & \\
\hline Possibility of independent working with the text & \\
\hline Possibility of a group working with the text & \\
\hline Length of the text & \\
\hline Overall complexity of the text & \\
\hline
\end{tabular}

All the information mentioned above may be reduced to a template (Table 1) that can be used to determine whether the selected text meets the requirements, needs, and skills of students at this stage of learning.

By grouping the given notes and analyzing the text with the template provided, the teacher will be able to determine whether the text meets the requirements and students' interests, as well as make a preliminary conclusion about the exercises that can be used in its analysis.

\section{References:}

1. Navchaljni proghramy z inozemnykh mov dlja zaghaljnoosvitnikh navchaljnykh zakladiv i specializovanykh shkil iz poghlyblenym vyvchennjam inozemnykh mov, 10-11 klasy [Curricula in foreign languages for secondary schools and specialized schools with in-depth study of foreign languages, grades 10-11]. Retrieved from: https://mon.gov.ua/storage/app/media/zagalna\%20serednya/programy-10-11-klas/20182019/ inozemni-movi-10-11-19.09.2017.pdf (accessed 27 June 2020). 
2. Vasjkova, N. M. (2018). Rozvytok tvorchykh zdibnostej uchniv pid chas roboty z tekstom na urokakh anghlijsjkoji movy u starshykh klasakh [Development of students' creative abilities while working with texts in English lessons in high school]. Retrieved from: https://naurok.com.ua/metodichni-rekomendaci-rozvitok-navichokkritichnogo-mislennya-uchniv-pid-chas-roboti-z-tekstom-na-urokah-angliysko-movi61637.html (accessed 28 June 2020).

3. Aksyutina, T. V. O sistemnom podkhode $\mathrm{k}$ razvitiyu navykov interaktivnogo chteniya na angliyskom yazyke $\mathrm{v}$ filosofii Whole Language [On a systematic approach to the development of interactive reading skills in English in Whole language philosophy]. Retrieved from: http://www.rusnauka.com/3_ANRR_2009/Pedagogica/ 40155.doc.htm (accessed 04 July 2020).

4. Pshonik, T. M. (2019). Metodychni rekomendaciji dlja pidboru tekstiv dlja rozvytku navychok chytannja na urokakh anghlijsjkoji inozemnoji movy v zaghaljnoosvitnij shkoli. [Methodical recommendations for the selection of texts for the development of reading skills in English language lessons in high school]. Retrieved from: https://naurok.com.ua/metodichni-rekomendaci-dlya-pidboru-tekstivdlya-rozvitku-navichok-chitanya-na-urokah-angliysko-movi-125436.html (accessed 28 June 2020).

5. The New Zealand Curriculum Update (2012). Selecting Texts for Students in Years 4 to 8 . Retrieved from: https://nzcurriculum.tki.org.nz/content/download/ 17060/180073/file/NZC-update-19.pdf (accessed 29 June 2020).

\section{TO THE ISSUE OF THE PECULIARITIES \\ OF LEARNING FOREIGN LANGUAGES IN THE SYSTEM OF PROFESSIONAL EDUCATION BY LAW ENFORCEMENT OFFICERS AND SERVICEMEN}

\section{Tetiana Serhiienko ${ }^{1}$ Yulia Samoilova ${ }^{2}$}

DOI: https://doi.org/10.30525/978-9934-588-84-6-6

Today, foreign languages hold an extremely important place in the education of any specialist. English is becoming the «lingua franca» (language of communication) within the European Union. Thus, it is important to organize vocational training of law enforcement officers and servicemen in English so that as a result of training they reach the level of

\footnotetext{
${ }^{1}$ Hetman Petro Sahaidachnyi National Army Academy, Ukraine

${ }^{2}$ Sumy branch of Kharkiv National University of Internal Affairs, Ukraine
} 